\title{
Identifikasi Cendawan Patogen pada Beberapa Varietas Benih Padi Sawah Berdasarkan Model Penyimpanan
}

\author{
Kresentia Amteme ${ }^{\mathrm{a}}$ dan Anna Tefa ${ }^{\mathrm{b}}$ \\ ${ }^{a}$ Fakultas Pertanian, Universitas Timor, Kefamenanu, TTU - NTT, Indonesia, email: kresentiaamteme@gmail.com \\ ${ }^{a}$ Fakultas Pertanian, Universitas Timor, Kefamenanu, TTU - NTT, Indonesia, email: annatefa@ rocketmail.com
}

\section{Article Info}

Article history:

Received 4 Juli 2017

Received in revised form 11 Maret 2018

Accepted 11 Maret 2018

\section{Keywords:}

Benih Padi

Identifikasi

Cendawan Patogen

Model Penyimpanan

\section{Abstrak}

Benih dikatakan sehat, apabila benih yang digunakan bebas dari mikroorganisme penyebab penyakit salah satunya adalah cendawan Tujuan penelitian ini adalah untuk mendapatkan jenis cendawan patogen yang menginfeksi benih padi. Penelitian dilaksanakan di laboratorium Fakultas Pertanian dan laboratorium Biologi Universitas Timor sejak bulan Maret - Mei 2017. Penelitian menggunakan Rancangan Acak Lengkap pola faktorial dengan dua faktor. Faktor pertama terdiri dari tiga varietas yakni Ciherang, IR dan Siputih. Faktor kedua terdiri dari model penyimpanan yakni penyimpanan dalam karung plastik, sokal dan kaleng. Hasil penelitian menunjukkan bahwa penggunaan tiga varietas dan model bahan pengemas benih tidak menunjukkan perbedaan nyata terhadap daya berkecambah. Persentase potensi tumbuh maksimum antara varietas siputih $(97,33)$ berbeda secara nyata dengan varietas IR $(72,00)$ dan pada model benih yang disimpan dalam karung plastik $(94,22)$ berbeda secara nyata dengan benih yang disimpan dalam sokal $(68,88)$. Hasil identifikasi ditemukan lima cendawan dari genus Aspergillus sp.1 dan sp.2, Altenaria, Curvularia, Fusarium dan Rhizopus yang menginfeksi benih sehingga menurunkan daya berkecambah. Tingkat serangan cendawan berbeda-beda pada varietas dan model penyimpanan. Kelima cendawan patogen yang ditemukan, dua cendawan diantaranya yaitu Aspergillus dan Fusarium menginfeksi benih dengan tempat penyimpanan yang berbeda lebih rendah, untuk mengurangi tingkat infeksi cendawan Altenaria, Curvularia dan Rhizopusdapat diberi perlakuan fungisida. O2018 dipublikasikan oleh Savana Cendana.

\section{Pendahuluan}

Padi (Oriza sativa L.) merupakan komoditas pangan pokok karena dikonsumsi sebagian besar penduduk Indonesia. Oleh karena itu, upaya peningkatan produksi telah banyak dilakukan. Namun, kendala yang sering dihadapi yang akhirnya menurunkan produksi padi adalah penggunaan benih padi yang kurang berkualitas. Keberhasilan budidaya tanaman ditentukan oleh mutu benih karena perannya tidak dapat digantikan oleh faktor lain.

Benih bermutu tinggi yaitu benih yang memiliki mutu genetik, fisiologi, dan fisik yang baik. Oleh karena itu, benih yang digunakan adalah benih yang bebas dari mikroorganisme/patogen seperti cendawan, bakteri, virus dan nematoda. Patogen pada benih dapat menimbulkan kerugian seperti penurunan daya kecambah, kerusakan bentuk fisik dan warna benih. Benih yang telah terinfeks pada saat disemaikan, pertumbuhan tanaman padi tidak merata sehingga ketika di pindahkan ke lapangan, tanaman menunjukkan gejala penyakit seperti kerdil karat daun, dan patah pada malai padi. Benih yang telah terinfeksi patogen tidak hanya menghambat pertumbuhan tanaman namun dapat pula menyebabkan keracunan (Sutopo 2002; Ominski et al., 1994) selanjutnya menurut Yuliant (2007), mengungkapkan bahwa patogen mampu hidup dan bertahan pada habitatnya di tanah, sisa tanaman dan gulma.

Model penyimpanan benih padi oleh sebagian petani di Kabupaten Timo Tengah Utara (TTU) khususnya desa T'eba masih bersifat tradisional yaitu menyimpan hasil panen termasuk untuk kebutuhan benih dengan cara mengemas benih dalam karung plastik, penyimpanan benih dalam sokal dan penyimpanan pada kemasan kaleng. Kebiasaan penyimpanan benih ini menjadi tradisi sejak dulu. Metode penyimpanan benih dengan model penyimpanan yang berbeda berpengaruh pada mutu benih. Model penyimpanan yang tidak tepat akan terjadi serangan cendawan patogen pada benih (Sutopo, 2002).

Penyimpanan benih padi yang baik dan benar akan dapat mempertahankan kualitas benih padi selama kurun waktu tertentu. Selama penyimpanan benih mengalami kerusakan. Beberapa faktor yang mempengaruhi kerusakan benih selama penyimpanan antara lain vigor awal benih, proses panen dan pasca panen termasuk kondisi lingkungan dan lama penyimpanan (Arief et al., 2004).

Permasalahan dalam penelitian ini adalah belum diketahui tentang jenis cendawan patogen yang menginfeksi benih padi pada model penyimpanan yang biasa dilakukan petani di desa sehingga perlu dilakukan penelitian, untuk mengetahui jenis cendawan patogen yang menginfeksi beberapa varietas benih padi sawah dengan model penyimpanan.

\section{Metode}

Penelitian dilaksanakan pada bulan Maret sampai bulan Mei 2017. Pengamatan secara mikroskopis di laboratorium Fakultas Pertanian dan laboratorium Biologi Universitas Timor, Kabupaten TTU. Bahan yang digunakan adalah benih padi varietas Ciherang, varietas IR, varietas Siputih, media Potato Dextrose Agar (PDA), alkohol $70 \%$ aquades, spirtus, chloramphenicol, kertas stensil. Alat yang digunakan antara lain mikroskop binokuler, germinator, cawan petri, kaca preparat, cover glass, lampu Buncen, tissu, masker, sarung tangan dan kertas label. Tata letak percobaan disusun dengan Rancangan Acak Lengkap (RAL) pola faktorialdengan dua faktor. Faktor pertama ialah varietas $(\mathrm{V})$ terdiri dari tiga aras yakni varietas ciherang $\left(\mathrm{v}_{1}\right)$ varietas IR $\left(\mathrm{v}_{2}\right)$, varietas siputih $\left(\mathrm{v}_{3}\right)$. Faktor kedua ialah model penyimpanan $(\mathrm{P})$ terdiri dari tiga aras yaitu penyimpanan dalam karung plastik $\left(\mathrm{p}_{1}\right)$, penyimpanan dalam sokal $\left(\mathrm{p}_{2}\right)$ dan penyimpanan dalam kaleng $\left(\mathrm{p}_{3}\right)$

Isolasi patogen dilakukan dengan menginkubasi benih padi pada cawan petri yang telah di sterilisasi. Benih ditanam dalam cawan petri berisi media PDA yang sebelumnya telah diberi Chloramphenicol untuk mencegah pertumbuhan bakteri, kemudian pemurnian cendawan yang tumbuh berdasarkan warna koloni Karakterisasi cendawan patogen dilakukan secara makroskopis dan mikroskopis
Pengamatan secara makroskopis yaitu pengamatan secara langsung melihat ciri khas koloni berupa bentuk, warna dan tepi koloni. Pengamatan secara mikroskopis yaitu pengamatan karakteristik cendawan berupa: Hifa seperti warna, bersekat atau tidak dan pola percabangan. Konidia berupa bentuk, warna dan ukuran. Konidiofor berupa warna, bersekat atau tidak, bercabang atau tidak dan ukuran konidiofor. Pengamatan cendawan patogen sesuai petunjuk Mathur \& Kongsdal, (2003)

Parameter pengujian kesehatan benih menggunakan metode uji kertas digulung didirikan pada plastik (UKDdP) meliputi daya berkecambah (DB) (\%) dan potensi tumbuh maksimum (PTM) (\%). Identifikasi karakter morfologi cendawan dengan menumbuhkan isolat cendawan pada media PDA berdasarkan genus cendawan, diinkubasi selama 4 hari kemudian pengamatan dengan mikroskop. Tujuan menumbuhkan isolat cendawan pada media PDA adalah untuk pengamatan karakter koloni cendawan. Pengamatan kejadian kontaminas cendawan patogen. Seluruh benih yang diinkubasi dalam cawan petri tersebut menjadi sampel. Kejadian penyakit dapat dihitung dari jumlah benih yang terinfeksipatogen. Pengamatan terhadap kejadian penyakit dilakukan disetiap cawan petri dengan menghitung jumlah benih terinfeksi penyakit berdasarkan jenis patogen. Analisis data dilakukan sesuai petunjuk (Gomez \& Gomez, 1984)

\section{Hasil dan Pembahasan}

\subsection{Daya berkecambah $(\%)$}

Daya berkecambah merupakan potensi kemampuan benih berkecambah setelah penanganan yang optimal sehingga dapat mencerminkan hasil kecambah yang diharapkan pada saat persemaian (Syamsu, 2003). Hasil analisis sidik ragam (Anova) menunjukkan tidak terjadi interaksi antara varietas dan model penyimpanan terhadap daya berkecambah $(\%)$. Hasil daya berkecambah benih pada beberapa varietas dan model penyimpanan tidak berbeda nyata.

\begin{tabular}{llrlc}
\multicolumn{2}{l}{ Tabel 1. Daya Berkecambah $(\%)$} & \multirow{2}{*}{ Rerata } \\
\cline { 2 - 4 } Model Penyimpanan & Ciherang & \multicolumn{1}{c}{ IR } & Siputih & \\
\hline Karung Plastik & $10,67 \mathrm{a}$ & $26,67 \mathrm{a}$ & $13,33 \mathrm{a}$ & $16,88 \mathrm{a}$ \\
Sokal & $20,00 \mathrm{a}$ & $5,33 \mathrm{a}$ & $22,67 \mathrm{a}$ & $16,00 \mathrm{a}$ \\
Kaleng & $26,67 \mathrm{a}$ & $6,67 \mathrm{a}$ & $14,67 \mathrm{a}$ & $16,00 \mathrm{a}$ \\
\hline Rerata & $19,11 \mathrm{a}$ & $12,89 \mathrm{a}$ & $16,66 \mathrm{a}$ & $(-)$ \\
\hline
\end{tabular}

Keterangan: Angka yang diikuti oleh huruf yang sama pada baris dan kolom menunjukan tidak berbeda nyata dengan uji DMRT pada taraf $5 \%$

Tiga varietas yang digunakan dalam penelitian ini, memiliki daya berkecambah rendah (Tabel 1.). Persyaratan sertifikasi untuk benih padi yang mensyaratkan nilai daya berkecambah minimal $80 \%$. Penyimpanan benih oleh petani di desa T'eba, dilakukan secara tradisional dan kondisi tempat penyimpanan serta faktor genetik benih menyebabkan kemunduran benih. Hasi penelitian Kartono (2004) menunjukkan bahwa walaupun kadar air penyimpanan rendah, penyimpanan pada ruang terbuka menyebabkan kerusakan benih yang tinggi, menurunkan daya kecambah, dan daya simpan benih yang singkat.

Selain kadar air dan lama penyimpanan, kondisi tempat penyimpanan yang kurang efektif menjadi peluang bagi cendawan patogen untuk menyerang benih Hal ini, membuktikan pada pengujian daya berkecambah dengan metode uji kertas digulung di dirikan dalam plastik (UKDdP), menunjukan bahwa terdapat benih padi yang tidak tumbuh (mati) pada 7 HST. Pada permukaan kulit benih terdapat bintik-bintik cokelatan dan isi dari benih telah membusuk sehingga menyebabkan benih tidak berkecambah (Gambar 1.) 


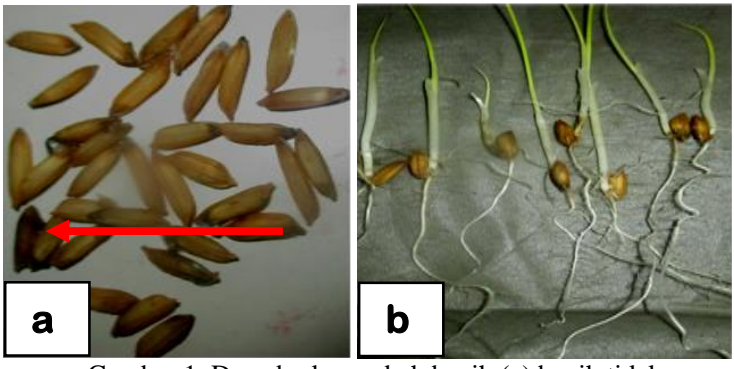

Gambar 1. Daya berkecambah benih (a) benih tidak berkecambah (mati), (b) kecambah normal

\subsection{Potensi Tumbuh Maksimum ( \%}

Potensi tumbuh maksimum adalah salah satu parameter viabilitas benih (Sutopo, 2002). Besarnya nilai potensi tumbuh maksimum menunjukan kondisi viabilitas benih yang tinggi (Justice \& Bass, 2002). Hasil sidik ragam (anova) menunjukan interaksi varietas dan model penyimpanan berpengaruh sangat nyata terhadap PTM (\%). Pengaruh utama varietas siputih dan penyimpanan dalam kemasan karung plastik menghasilkan PTM dengan persentase tertinggi. Model penyimpanan dalam karung plastik, berbeda secara nyata dengan mode penyimpanan dalam kemasan sokal (Tabel 2.).

Tabel 2. Potensi Tumbuh Maksimum (\%)

\begin{tabular}{llllc}
\hline \multirow{2}{*}{ Model Penyimpanan } & \multicolumn{3}{c}{ Varietas } & \multirow{2}{*}{ Rerata } \\
\cline { 2 - 4 } & Ciherang & IR & Siputih & \\
\hline Karung Plastik & $90,66 \mathrm{ab}$ & $93,33 \mathrm{ab}$ & $98,66 \mathrm{a}$ & $94,22 \mathrm{a}$ \\
Sokal & $82,66 \mathrm{~b}$ & $26,66 \mathrm{c}$ & $97,33 \mathrm{a}$ & $68,88 \mathrm{~b}$ \\
Kaleng & $88,00 \mathrm{ab}$ & $96,00 \mathrm{a}$ & $96,00 \mathrm{a}$ & $93,33 \mathrm{a}$ \\
\hline Rerata & $87,11 \mathrm{~b}$ & $72,00 \mathrm{c}$ & $97,33 \mathrm{a}$ & $(+)$ \\
\hline
\end{tabular}

Keterangan: Angka yang diikuti oleh huruf yang berbeda pada barisdan kolom menunjukanberbeda nyata dengan uji DMRT pada taraf5\%

Potensi tumbuh maksimum merupakan benih yang tumbuh baik, yang normal maupun abnormal pada batas waktu tertentu. Benih yang disimpan dengan baik mempunyai daya tumbuh yang tinggi saat ditanam kembali. Varietas siputih dan penyimpanan menggunakan karung plastik mempertahankan mutu fisiologis benih dan dapat menghambat kecepatan kemunduran benih atau deteriorasi. Hal ini mengindikasikan bahwa benih siputih dengan penyimpanan pada karung plastik memiliki viabilitas yang baik.

\subsection{Persentase kejadian penyakit (PKP)}

Pengamatan kejadian penyakit menunjukan tidak terjadi interaksi antara varietas dan model penyimpanan (Anova). Dari hasil pengamatan PKP (\%), jumlah benih padi dari setiap varietas dengan model penyimpanan yang berbeda terinfeksi cendawan patogen.

Tabel 3. PKP $(\%)$

\begin{tabular}{lllll}
\hline \multirow{2}{*}{ Model Penyimpanan } & \multicolumn{3}{c}{ Varietas } & \multirow{2}{*}{ Rerata } \\
\cline { 2 - 4 } & Ciherang & IR & Siputih & \\
\hline Karung Plastik & 100 & 100 & 100 & $100 \mathrm{a}$ \\
Sokal & 100 & 100 & 100 & $100 \mathrm{a}$ \\
Kaleng & 100 & 100 & 100 & $100 \mathrm{a}$ \\
\hline Rerata & $100 \mathrm{a}$ & $100 \mathrm{a}$ & $100 \mathrm{a}$ & $(-)$ \\
\hline
\end{tabular}

Keterangan: Angka yang diikuti oleh huruf yang sama pada baris dan kolom menunjukan tidak berbeda nyata dengan uji DMRT pada taraf $5 \%$.

Setiap benih yang di inkubasi dalam media PDA, terinfeksi cendawan patogen. Temuan cendawan yang cukup banyak pada benih padi diduga karena benih telah mengalami proses penyimpanan yang cukup lama, kondisi penyimpanan benih padi yang lembab dan cara penyimpanan benih oleh petani yang sangat sederhana akan memperburuk kondisi kesehatan benih. Semangun (2008) melaporkan padi dan beras yang disimpan secara kurang baik akan terserang oleh bermacam-macam cendawan.

\subsection{Persentase Infeksi Cendawan Aspergillus sp $_{1}$}

Hasil analisis sidik ragam (anova) menunjukan tidak terjadi pengaruh interaksi antara varietas dan model penyimpanan terhadap cendawan patogen.

Tabel 4. Cendawan Aspergillus $\mathrm{sp}_{._{1}}$

\begin{tabular}{lllll}
\multirow{2}{*}{ Model Penyimpanan } & \multicolumn{3}{c}{ Varietas } & \multirow{2}{*}{ Rerata } \\
\cline { 2 - 4 } & Ciherang & IR & Siputih & \\
\hline Karung Plastik & $21,33 \mathrm{a}$ & $2,67 \mathrm{a}$ & $22,67 \mathrm{a}$ & $15,56 \mathrm{a}$ \\
Sokal & $22,67 \mathrm{a}$ & $0,00 \mathrm{a}$ & $65,33 \mathrm{a}$ & $29,33 \mathrm{a}$ \\
Kaleng & $36,00 \mathrm{a}$ & $0,00 \mathrm{a}$ & $60,00 \mathrm{a}$ & $32,00 \mathrm{a}$ \\
\hline Rerata & $26,67 \mathrm{ab}$ & $0,89 \mathrm{~b}$ & $49,33 \mathrm{a}$ & $(-)$
\end{tabular}

Keterangan: Angka yang diikuti oleh huruf yang sama pada baris dan kolom menunjukan tidak berbeda nyata dengan uji DMRT pada taraf 5\%.
Berdasarkan pengamatan ditemukan cendawan Aspergillussp., 1 menginfeksi varietas siputih dengan tingkat infeksi tertinggi yang berbeda secara nyata dengan varietas IR danCiherang. Serangan cendawan pada model penyimpanandalam kemasan kaleng lebih tinggi namun tidak berbeda nyata dengan model penyimpanan dalam karung plastik dan sokal.

\subsection{Persentase Infeksi Cendawan Aspergillus $\mathrm{sp}_{2}$}

Hasil analisis sidik ragam (Anova) menunjukan tidak terjadi pengaruh interaksi antara perlakuan. Tingkat serangan cendawan Aspergilus sp..2pada varietas ciherang dan benih yang disimpan dalam sokal lebih tinggi. Persentase infeksi cendawan dapat dilihat pada Tabel 5 .

\begin{tabular}{lcllr}
\multicolumn{3}{l}{ Tabel 5. Aspergillus sp.2 } \\
\cline { 2 - 4 } Model Penyimpanan & \multicolumn{3}{c}{ Varietas } & \multirow{2}{*}{ Rerata } \\
\cline { 2 - 4 } & Ciherang & IR & Siputih & \\
\hline Karung Plastik & $0,00 \mathrm{a}$ & $0,00 \mathrm{a}$ & $5,33 \mathrm{a}$ & $1,77 \mathrm{a}$ \\
Sokal & $24,00 \mathrm{a}$ & $1,33 \mathrm{a}$ & $9,33 \mathrm{a}$ & $11,55 \mathrm{a}$ \\
Kaleng & $17,33 \mathrm{a}$ & $2,67 \mathrm{a}$ & $0,00 \mathrm{a}$ & $6,66 \mathrm{a}$ \\
\hline Rerata & $13,77 \mathrm{a}$ & $1,33 \mathrm{a}$ & $4,88 \mathrm{a}$ & $(-)$ \\
\hline
\end{tabular}

Keterangan: Angka yang diikuti oleh huruf yang sama pada baris dan kolom menunjukan tidak berbeda nyata dengan uji DMRT pada taraf 5\%.

Hasil pengamatan secara mikroskopis ditemukan cendawan dari genus Aspergillus sp,.1 dan sp.,2 mengenfiksi benih IR dengan model penyimpanan dalam karung plastik sangat rendah (Tabel 4. dan Tabel 5.). Karung plastik merupakan kemasan benih yang bersifat porous sehingga sirkulasi uap udara secara bebas bergerak dalam karung. Cendawan Aspergillus merupakan cendawan fakultatif atau cendawan gudang. Cendawan ini, menginfeksi benih dengan kadar air $13-18 \%$ serta suhu dan kelembaban berkisar antara $20^{\circ}-30^{\circ} \mathrm{C}$, kondisi tempat penyimpanan benih yang kurang efektif dimana benih yang disimpan dalam sokal diletahkan begitu saja pada lantai sehingga menyebabkan kelembaban yang tinggi disekitar tempat penyimpanan, hal ini menjadi salah satu peluang bagi cendawan untuk menginfeksi benih.
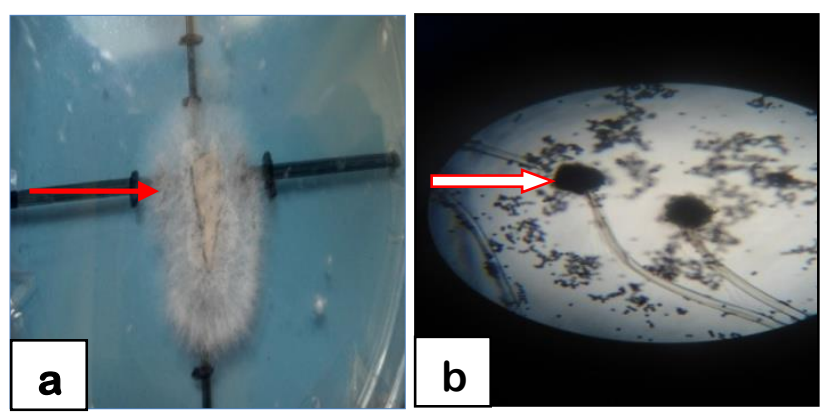

Gambar 2. Bentuk koloni dan morfologi Aspergillus $\mathrm{sp}_{1 .}$ a, koloni pada media PDA; dan b, konidiaAspergillus $\mathrm{sp}_{1}$

Koloni cendawan Aspergillus sp., berwarna putih, coklat kehitaman. Kepala konidia adalah struktur terletak dibagian struktur konidiofor. Pada bagian apeksnya membentuk suatu struktur globose, konidiofor merupakan suatu struktur tegak lurus yang muncul dari sel kaki dan pada ujungnya menghasilkan kepala konidia. Konidiofor tidak bercabang yang masing-masing menghasilkan kepala konidia tunggal.

\subsection{Persentase Infeksi Cendawan Altenaria sp.}

Hasil analisis sidik ragam (Anova) menunjukan tidak terjadi pengaruh interaksi antara verietas dan model penyimpanan. Cendawan Altenaria sp menginfeksi varietas IR dengan benih yang disimpan dalam karung plastik berbeda secara nyata dengan perlakuan lainnya.

\section{Tabel 6. Cendawan Altenaria}

\begin{tabular}{lllrl}
\hline \multirow{2}{*}{ Model Penyimpanan } & \multirow{3}{*}{ Rerata } \\
\cline { 2 - 4 } & Ciherang & IR & Siputih & \\
\hline Karung Plastik & $44,00 \mathrm{a}$ & $64,00 \mathrm{a}$ & $38,67 \mathrm{a}$ & $48,89 \mathrm{a}$ \\
Sokal & $21,33 \mathrm{a}$ & $33,33 \mathrm{a}$ & $24,00 \mathrm{a}$ & $26,22 \mathrm{a}$ \\
Kaleng & $18,67 \mathrm{a}$ & $33,33 \mathrm{a}$ & $0,00 \mathrm{a}$ & $17,33 \mathrm{a}$ \\
\hline Rerata & $28,00 \mathrm{a}$ & $43,56 \mathrm{a}$ & $20,89 \mathrm{a}$ & $(-)$ \\
\hline
\end{tabular}

Keterangan: Angka yang diikuti oleh huruf yang sama pada baris dan kolom menunjukan tidak berbeda nyata dengan uji DMRT pada taraf $5 \%$

Tingkat serangan cendawan berbeda-beda pada setiap perlakuan. Cendawan Altenaria menginfeksi varietas IR dengan model penyimpanan menggunakan kemasan karung plastik sangat tinggi. Cendawan Altenaria merupakan cendawan terbawa benih karena cendawan tersebut merupakan patogen tanaman padi. Varietas siputih dengan model penyimpanan dalam kemasan kaleng dapat mengurangi tingkat infeksi cendawan (Tabel 6.). Hal ini disebabkan karena kaleng terbuat dari alumunium, selain itu kaleng juga tertutup rapat. 


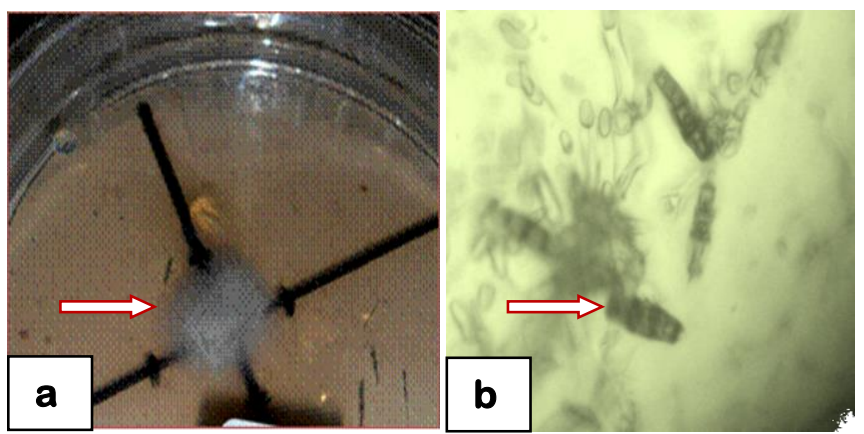

Gambar 3. Bentuk koloni dan morfologi Altenaria sp. a, koloni Altenariapada media PDA dan b, konidia.

Koloni cendawan berwarna putih keabuan sampai kehitaman. Arah pertumbuahan miselium kesamping dan stuktur miselium kasar. Pada hari ke 23 koloni memenuhi cawan petri. Secara umum, pertumbuhan altenaria sp., sangat cepat pada medium PDA. Percabangan hifa sedikit, bersekat dan berwarna gelap. Bentuk konidia memanjang, bersekat dan berwarna coklat. Cendawan ini dapat menginfeksi pada suhu dingin.

\subsection{Persentase Infeksi Cendawan Curvularia, Rhizopus}

Hasil analisis sidik ragam (Anova) menunjukan tidak terjadi pengaruh interaksi antara perlakuan. Pada pengamatan ditemukan cendawan Curvularia dan Rhizopuz berasosiasi menginfeksi benih padi varietas IR paling tinggi dengan model penyimpanan menggunakan kaleng.

Tabel 7. Cendawan Curvularia dan Rhizopuz

\begin{tabular}{lclrc}
\hline \multirow{2}{*}{ Model Penyimpanan } & \multicolumn{3}{c}{ Varietas } & \multirow{2}{*}{ Rerata } \\
\cline { 2 - 4 } & Ciherang & IR & Siputih & \\
\hline Karung Plastik & $33,33 \mathrm{a}$ & $33,33 \mathrm{a}$ & $32,00 \mathrm{a}$ & $32,89 \mathrm{a}$ \\
Sokal & $0,00 \mathrm{a}$ & $65,33 \mathrm{a}$ & $0,00 \mathrm{a}$ & $21,78 \mathrm{a}$ \\
Kaleng & $28,00 \mathrm{a}$ & $64,00 \mathrm{a}$ & $40,00 \mathrm{a}$ & $44,00 \mathrm{a}$ \\
\hline Rerata & $20,44 \mathrm{a}$ & $54,22 \mathrm{a}$ & $24,00 \mathrm{a}$ & $(-)$ \\
\hline
\end{tabular}

Keterangan: Angka yang diikuti oleh huruf yang sama pada baris dan kolom menunjukan tidak berbeda nyata dengan uji DMRT pada taraf 5\%.

Data Tabel 7. menunjukan bahwa varietas IR rentan terhadap serangan cendawan. Hal ini disebabkan karena dua jenis cendawan dari genus yang berbeda berasosiasi untuk menginfeksi benih. Benih yang disimpan dalam kaleng cenderung lebih tinggi sedangkan benih yang disimpan dalam sokal tingkat infeksi cendawan rendah.

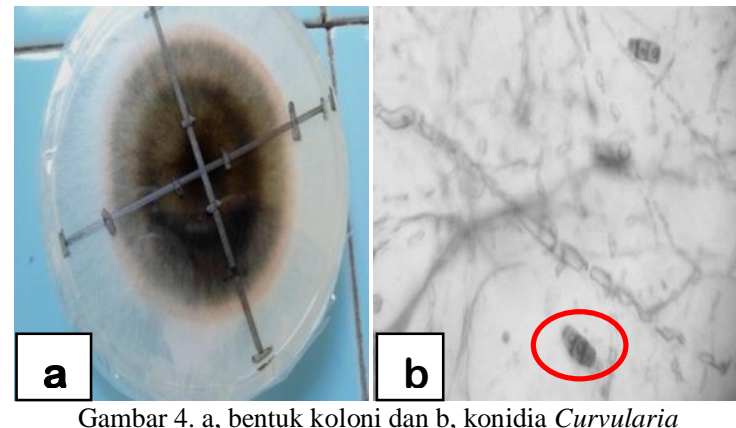

Konidia Curvularia berbentuk huruf C, bagian tengah membesar dan semakin tumpul pada ujung konidia. Konidia bersekat (3-4 sekat), dinding yang tebal berwarna cokelat kehitaman. Konidia berwarna cokelat dan berukuran 16-26 um x 8-12 um (Michel et al, 2013). Infeksi melalui stomata kemudian menyebar ke jaringan tanaman.
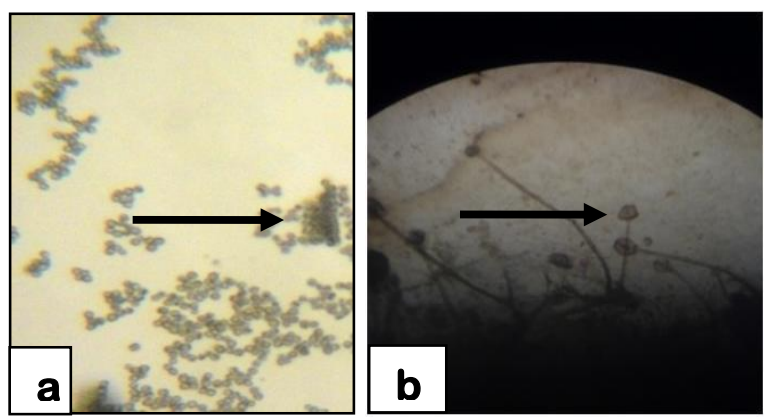

Gambar 5. (a) Spora dan (b) Konidia Rhizopus

Cendawan Rhizopusmerupakan cendawan gudang atau cendawan pada tempat penyimpanan. Spora berwarna hitam, sporagiofor bertangkai tumbuh keatas dan mengandung ratusan spora dan biasanya dipisahkan dari hifa oleh sebuah dinding dan sekat. Bentuk spora menyerupai globose sampai oval, konidia berwarna hitam dan berukuran $5-15 \mu \mathrm{m}$.

\subsection{Persentase Infeksi Cendawan Fusarium sp}

Hasil analisis sidik ragam (Anova) menunjukan tidak terjadi pengaruh interaksi antara perlakuan verietas dan model penyimpanan. Data Tabel 8 . menunjukan tingkat infeksi cendawan Fusariumpada varietas dan IR dan siputih dengan benih yang disimpan dalam karung plastik dan kaleng cenderung lebih rendah.

\begin{tabular}{lcllc}
\multicolumn{2}{l}{ Tabel 8. Cendawan Fusarium } \\
\cline { 2 - 4 } Model Penyimpanan & \multirow{2}{*}{ Rerata } \\
\cline { 2 - 4 } & Ciherang & IR & Siputih & \\
\hline Karung Plastik & $0,00 \mathrm{a}$ & $0,00 \mathrm{a}$ & $1,33 \mathrm{a}$ & $0,44 \mathrm{a}$ \\
Sokal & $28,00 \mathrm{a}$ & $0,00 \mathrm{a}$ & $1,33 \mathrm{a}$ & $9,77 \mathrm{a}$ \\
Kaleng & $0,00 \mathrm{a}$ & $0,00 \mathrm{a}$ & $0,00 \mathrm{a}$ & $0,00 \mathrm{a}$ \\
\hline Rerata & $9,33 \mathrm{a}$ & $0,00 \mathrm{a}$ & $0,88 \mathrm{a}$ & $(-)$
\end{tabular}

Keterangan: Angka yang diikuti oleh huruf yang sama pada baris dan kolom menunjukan tidak berbeda nyata dengan uji DMRT pada taraf $5 \%$

Model penyimpanan benih tidak berpengaruh secara nyata terhadap tingkat serangan cendawan menunjukan bahwa benih yang disimpan dalam karung plastik dan kaleng resisten terhadap serangan cendawan Fusarium. Sebaliknya benih yang disimpan dalam sokal, terinfeksi cendawan lebih tinggi.
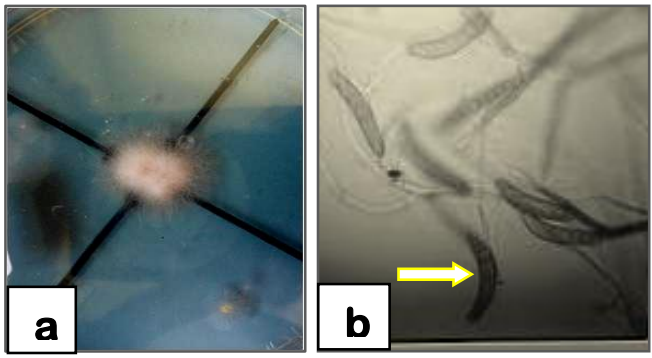

Gambar 6. Bentuk koloni dan morfologi Fusarium sp. a, koloni pada medium agar-agar dekstrosa kentang dan b, konidia Fusarium sp.

Cendawan Fusarium merupakan patogen terbawa benih. Ciri konidia berbentuk oval, terdiri dari 7 septa berwarna hialin, bagian tengahnnya membesar, kedua ujung konidia meruncing seperti bulan sabit (Gambar 6.).

Benih yang disimpan dalam sokal, diletahkan begitu saja pada rak penyimpanan dari kayu (bale-bale). Kondisi tempat penyimpanan yang mendukung menjadi peluang bagi cendawan ini untuk menginfeksi benih. sedangkan benih yang disimpan dalam kaleng tidak terinfeksi cendawan.

\subsection{Pembahasan}

Benih varietas siputih yang disimpan dalam kemasan karung plastik dan kaleng memilikipersentase potensi tumbuh maksimumyang baik, sedangkan prosentase daya berkecambah antara varietas dan model penyimpanan sangat rendah. Tingkat serangan cendawan pada varietas dan model penyimpanan berbeda-beda sesuai dengan kondisi tempat penyimpanan. Cendawan Aspergillus sp.,1 dan Aspergillus sp.,2 menginfeksi varietas IR dengan benih yang disimpan dalam karung plastik lebih rendah sebaliknya cendawan Altenariamenginfeksi varietas IR dan model penyimpanan dalam karung plastik lebih tinggi. Cendawan Curvularia dan Rhizopuz berasosiasi menginfeksi benih yang disimpan dalam kaleng dengan varietas IR tertinggi selanjutnya keberadaan cendawan Fusarium menginfeksi benih pada model penyimpanan yang berbeda cenderung lebih rendah.

Beberapa varietas yang digunakan oleh petani untuk budidaya, telah terinfeksi cendawan patogen. Penggunaan benih secara terus menerus menjadi salah satu faktor bagi cendawan bertahan dalam habitatnya (Yulianti, 2007).

Model penyimpanan tradisional, dengan mengemas benih dalam beberapa wadah yang tidak memadai serta kondisi lingkungan mendukung, menjadi salah satu peluang bagi cendawan untuk menginfeksi benih. Dampak kerugian serangan cendawan pada benih dapat mempengaruhi kehilangan daya tumbuh ataupun penurunan viabilitas benih (Tefa, 2016).

\section{Simpulan}

Terdapat serangan cendawan patogen pada beberapa varietas benih padi sawah dengan model kemasan yang berbeda. Jenis cendawan patogen berasal dari genus Aspergillussp., Altenaria, Culvularia, Fusarium dan Rhizopus. Tingkat serangan cendawan berbeda-beda pada varietas dan model penyimpanan, dari kelima cendawan patogen yang ditemukan, dua cendawan diantaranya yaitu Aspergillus dan Fusarium menyerang benih dengan tempat penyimpanan yang berbeda lebih rendah, untuk mengurangi serangan cendawan Altenaria, Curvularia dan Rhizopus diberi perlakuan fungisida. 


\section{Pustaka}

Arief, R., S. Syamu'un dan S. Saenong. 2004. Evaluasi mutu fisik dan fisiologi benih jagung Cv. Lamuru dari ukuran biji dan umur simpan yang berbeda. Jurnal Sains dan Teknologi, 4(2): 54-64. Dep Agriculture. U.S. Govt. Print.

Gomez, K.A. \& Gomez, A.A. 1984. Statistical Procedures for Agricultural Research. New York: John Wiley \& Sons.

Justice, O.L. L.N. Bass. 2002. Prinsip dan Praktek Penyimpanan Benih. Jakarta: Raja Grafindo Persada.

Kartono, 2004. Teknik penyimpanan benih kedelai varietas wilis pada kadar air dan suhu penyimpanan yang berbeda. Buletin teknik pertanian volume 9 nomor 2 tahun 2004.

Mathur, S.B. \& Kongsdal, O. 2003. Common laboratory seed health testing methods for detecting fungi. Bassersdorf, Switzerland: International Seed Testing Association.

Michael R, Anderson, Christina LJ, James CW, Meg AR. 2013. Anesthesia forpatients undergoing orthopedic oncologic surgeries. J Clin Anesth [Internet]. 2010 [cited 2013 November 24]; 22:565-72. Available from: EBSCO.

Ominski, K. H., R.R. Marquardt, R. N. Sinha and D. Abramson. 1994. Ecological aspects growth and mycotoxin production by storage fungi. in: Miller, J.D., Trenholm, H.L. (eds). Mycotoxins in grain: compound other than aflatoxin. Minnesota: Eagan Pr. pp. 287-312.

Semangun, H. 2008. Penyakit-PenyakitTanaman Pangan Di Indonesia. Yogyakarta: Gadjah Mada University Press.

Sutopo, L. 2002. Teknologi Benih. Jakarta: Rajawali Press.

Syamsu, W., Yubiarti N., Kurniaty R., \& Abidin, Z. 2003. Teknik penanganan benih orthodok. (buku 1). Bogor: Badan Penelitian dan pengembangan Kehutanan.

Tefa, A., Widajati, E., Syukur, M. \& Giyanto. 2016. Pemanfaatan Bakteri Probiotik untuk Menekan Infeksi Colletotrichum acutatum dan Meningkatkan Mutu Benih Cabai (Capsicum annuum L.) Selama Penyimpanan. Savana Cendana, 1(01): 38-42.

Yulianti. 2007. Pengaruh hama dan penyakit benih selama pengolahan dan penyimpanan terhadap viabilitas benih dan vigor bibit di persemaian. Laporan hasil penelitian. Bogor: Balai Litbang Teknologi Perbenihan. 